\title{
Compensation for Victims of Crime
}

In recent years considerable attention has been directed to a wide variety of programs for assisting victims of misfortune. Late arrivals on the scene, and curious hybrids as well, are proposals to compensate victims of crime. Reflecting both the social welfare philosophy which underlies medicare and the search for supplements to private law relief illustrated by the automobile compensation plans, ${ }^{1}$ the proposals for victims of crime have occasioned extensive legislative ${ }^{2}$ and popular interest ${ }^{3}$ in the few years that have elapsed since the idea was first proposed. 4

The novelty of the compensation plans lies less in their content than in the emergence of a demand that such a program be undertaken. The sudden fashionability of the idea may be traced in part to the adoption of schemes in Great Britain ${ }^{5}$ and in New Zealand, ${ }^{6}$ which have

1 For recent contrasting views of proposals to reform the present system of automobile accident litigation, compare Blum \&. Kalven, Public Law Perspectives on a Private Law Problem: Auto Compensation Plans (1965), originally printed in 31 U. ChI. L. Rev. 641 (1964), with Keeton \& O'Connell, Basic Protection for the Traffic Victim: A BluePRINT FOR REFORMING AUTOMOBILE INSURANCE (1965).

2 California, the first state to adopt compensation legislation, enacted two laws in 1965. Cal. Pen. Code §§ 13600-03 (a "Good Samaritan" law); Cal. Welfare \& Inst'ns Code $\$ 11211$. Other states in which proposals have been or are expected to be introduced include Illinois (Chicago Sun-Times, March 30, 1966, p. 35, col. 1); Maryland (S. Bill 151, Feb. 4, 1966); New Jersey (N.Y. Times, Jan. 2, 1966, p. 62, col. 1); New York (N.Y. Times, Oct. 24, 1965, p. 1, col. 5); Oregon (H. Bill 1822, March 4, 1965); and Wisconsin (S. Bill 450, April 1965). On the local level, New York City enacted an ordinance to assist Good Samaritans. NEW YoRK, N.Y., ADMIN. CODE § 67-3.2 (1965). Several federal bills have also been introduced: S. 2155, 89th Cong., Ist Sess. (1965) (Senator Yarborough) [hereinafter cited as S. 2155]; H.R. 11818, 89th Cong., Ist Sess. (1965) (Representative Green) [hereinafter cited as H.R. 11818]; H.R. 11552, 89th Cong., 1st Sess. (1965) (Representative Hathaway); H.R. 11291, 89th Cong., 1st Sess. (1965) (Representative Matsunaga); H.R. 11211, 89th Cong., 1st Sess. (1965) (Representative Bingham); H.R. 10896, 89th Cong., 1st Sess. (1965). The Yarborough bill, of which all the other bills except that proposed by Representative Green are replicas, applies only to the District of Columbia and to outlying territories. The Green proposal would establish a national compensation scheme.

3 The Gallup poll reports that 62 per cent of "a representative group of American voters" would favor state compensation for the family of an innocent person killed by a criminal. Gallup Poll, Press Release, Oct. 29, 1965.

4 Compensation was first seriously proposed in England in Fry, Justice for Victims, The Observer (London), July 7, 1957, p. 8, col. 2, reprinted in Compensation for Victims of Criminal Violence: A Round Table, 8 J. PuB. L. 191 (1959).

5 The British scheme, which is nonstatutory, was announced by the government in a White Paper, Compensation for Victims of Crimes of Violence, CMND. 2323 (1964) [herein- 
been extensively reported in this country. ${ }^{7}$ In addition, heightened public concern over increasing crime rates ${ }^{8}$ has led to demands for improved law enforcement and for other measures for the protection of the public, ${ }^{9}$ while dismay over the unwillingness of citizens to act as "Good Samaritans" has provoked desire to recompense those who come to the aid of others. ${ }^{10}$ The degree of interest which the compensation proposals have generated is nonetheless remarkable in that until a few years ago the possibility had received virtually no serious consideration; perhaps for that reason, much discussion of it has seemed undirected and superficial. It thus seems appropriate at this time to set out some of the proposals which have been made, to examine the justifications advanced for them, and to pose some of the problems with which any scheme must deal.

\section{Compensation for Victims: Alternative Rationales}

Since individuals are expected to bear the consequences of many kinds of misfortune, proponents of compensation schemes have been unable to demonstrate that victims of crime should be compensated

after cited as CMND. 2323]. The adoption of the plan was preceded by the report of a Government-appointed committee known as the Working Party, also published as a White Paper, Compensation for Victims of Crimes of Violence, CMND. 1406 (1961) [hereinafter cited as CMND. 1406]. See also a reply to the Working Party's report by the Justice Society (British Section of the International Commission of Jurists), COMPENSATION FOR VICTIM of Crimes of Violence 1962 [hereinafter cited as Justice Report].

6 Criminal Injuries Compensation Act, 1963, No. 134 [hereinafter cited as N.Z. Pub. Act 134].

7 E.g., Anderson, Should We Pay Crime Victims?, Parade Magazine, Nov. 8, 1964, p. 4; N.Y. Times, Feb. 21, 1965, \& 6 (Magazine), p. 19; N.Y. Times, March 24, 1964, p. 1, col. 7 (comment on British proposal); N.Y. Times, Sept. 22, 1963, p. 26, col. I (New Zealand scheme); Cameron, Compensation for Victims of Crime: The New Zealand Experiment, 12 J. PUB. L. 367 (1963); Note, Great Britain Approves Compensation Program for Victims of Criminal Violence, 78 HARV. L. REV. 1683 (1965).

8 According to the FBI, the number of "serious offenses" (murder and non-negligent manslaughter, forcible rape, aggravated assault, burglary, robbery, larceny over $\$ 50$ and auto theft) increased $11 \%$ from 1963 to 1964 . The rate of violent crime (including robbery), taking into account population growth, increased $27 \%$ from 1958; the comparable figure for property offenses was $46 \%$. FBI, UNIFORM CRIME REPORTS-1964, at 2-5. The reliability of the FBI statistics has, however, been seriously questioned. See BEL,, THE END OF IDEOLOGY 137-44 (1960).

9 E.g., President Johnson's declaration of "War on Crime." Establishing the President's Commission on Law Enforcement and Administration of Justice, Exec. Order No. 11236, 30 Fed. Reg. 9349 (1965).

10 See General Remarks by Norval Morris, Professor of Law and Criminology, The University of Chicago Law School, commenting on the morning session of the Conference on "the Good Samaritan and the Bad," Friday, April 9, 1965, at the Law School of The University of Chicago (mimeo). This and other papers from the Conference will be published by Doubleday in September, 1966. 
simply by observing that they need assistance. Instead, the various proposals for shifting losses from victims of crime have relied on three principal arguments, which have been used to support one another ${ }^{11}$ but may be stated in the alternative: (1) that the offender has an obligation to make restitution to the victim, and the state an obligation either to expedite such relief or to offer a substitute; (2) that the state is liable because it has failed to fulfill its duty to protect its citizens; and (3) that the state should assume a general social responsibility to aid unfortunates when, as here, such aid would serve compelling social policies.

\section{A. Restitution}

Tort and criminal law derived from the same stem and restitution was once awarded to victims as an incident of criminal prosecution. ${ }^{12}$ Nevertheless the two actions gradually became distinct and today, apart from occasional statutes which permit courts to order offenders convicted of certain crimes to make payments to their victims in lieu of punishment or as a condition of probation, ${ }^{13}$ it is the general rule that the victim may not be a party to criminal proceedings but must seek relief in a separate civil action. ${ }^{14}$ The victim's private remedy is of little

11 See, e.g., Fry, supra note 4.

12 The offender and his family were obligated to make payments to the victim and his family; at the same time, the offender might also be required to make a payment to the king or lord. See 2 Pollock \& MaItLAND, History of ENGLish LAw 449-62 (2d ed. 1898); Wolfgang, Victim Compensation in Crimes of Personal Violence, 50 MrN. L. REv. 223, 227-28 (1965).

13 Under federal law, a court may require an offender to make restitution as a condition of probation. 18 U.S.C. \$ 3651 . For discussion of various state statutes see Covey, Alternatives to a Compensation Plan for Victims of Physical Violence, 69 Dick. L. Rev. 391, 400 (1965); Note, Restitution and the Criminal Law, 39 CoLum. L. REv. 1185, 1190-97 (1939). Restitution orders are used infrequently, however. See Schultz, The Violated: $A$ Proposal To Compensate Victims of Violent Crime, 10 Sr. Louls U.L.J. 238, 248-44 (1965).

14 The actions may be brought in any order and the decision in one does not affect the other. ProssER, ToRTS $\S \S 2,7-9$ (3d ed. 1964); Hitchler, Crimes and Civil Injuries, 39 DrCK. L. REv. 23, 32 (1934). The rule in most jurisdictions that evidence of a criminal conviction is not admissible in a subsequent civil action has been under attack, however, and may be breaking down. See Bush, Criminal Convictions as Evidence in Civil Proceedings, 29 MIss. L. Rev. 276 (1958); Note, Admissibility and Conclusiveness of Criminal Conviction in Subsequent Civil Action, 16 MERCER L. REv. 464 (1965) (commenting on Hurtt v. Stirone, 416 Pa. 493, 206 A.2d 624 (1965) (evidence of defendant's prior conviction for extortion held conclusive of the fact of extortion in a later civil action by the victim to recover the money)); Note, Use of Record of Criminal Conviction in Subsequent Civil Action Arising From the Same Facts as the Prosecution, 64 Mrcr. L. Rev. 702 (1966). Support for the view that evidence of conviction should be admissible may be found in MCCORMICK, EVIDENCE \& 295 (1954); WIGMORE, EVIDENCE § 1671(a) (3d ed. 1940); UNIFORM RULE OF EVIDENCE 63(20) (1953).

The rule that the victim must prove his case in an independent civil action is not followed in many European countries; there the awarding of restitution in criminal 
utility in practice, ${ }^{15}$ however, as criminals are not always apprehended and, when found, are likely to be financially irresponsible, ${ }^{16}$ particularly as they cannot like other tort-feasors protect themselves in advance by means of liability insurance. ${ }^{17}$ The prospects for a successful civil action are further diminished by criminal prosecution, which not only subjects the offender to the costs of his defense but, more significantly, to penal sanctions of imprisonment and fines. The inefficacy of the civil remedy, in part a consequence of the strong public interest in punishing criminal conduct, ${ }^{18}$ has led some commentators to urge that the historical cycle be completed by state intervention to enforce the victim's claim for restitution. ${ }^{19}$

Attempts to revive restitution in the context of the present penal system suggest that the idea has fundamental shortcomings. California recently enacted legislation which provides public welfare assistance to victims incapacitated by crimes of violence through the imposition of fines on offenders convicted of such crimes in addition to other penal sanctions imposed. ${ }^{20}$ As the law does not resolve the difficulty posed by

proceedings is relatively common, and in some instances the victim may be a party in a criminal trial. See generally SchafER, Restitutron to VIctims (1960) (comparative law study of provisions for restitution in different legal systems); Silving, Comment on the Proposal, Compensation for Victims of Criminal Violence: A Round Table, 8 J. PuB. L. 236 (1959). Suggestions that, in light of that experience, joinder of civil and criminal actions or extension of the sentencing court's power to order restitution be allowed as suitable alternatives to compensation raise several difficulties, however. See Covey, supra note 13, at 402-04.

15 See, e.g., Mueller, Comment on the Proposal, Compensation for Victims of Criminal Violence: $A$ Round Table, 8 J. PuB. L. 218, 234 (1959).

16 Cf. Atrorney General's Committee on Poverty and the Administration of Federal CRIMINAL JUsTICE, REPORT (1963) (finding that a significant number of accused are unable to afford legal representation, to make bail, or to finance an appeal).

17 Insurance against criminal liability is proscribed both on grounds of public policy and by the insurance principle that only those risks are insurable which are not subject to the control of the parties to the contract. VANCE, INSURANce 90-91 (3d ed. 1951). The rule is not applied to minor traffic violations or to offenses which are mala prohibita rather than mala in se. See McNeeley, Illegality as a Factor in Liability Insurance, 41 Colum. L. REv. 26 (1941).

18 The coincidence of criminal and civil actions may also limit the victim's freedom to effect a private settlement with the offender. While the law in other areas encourages private settlement, the victim of crime who accepts restitution in return for an agreement to remain silent himself commits the offense of compounding a felony. There is nothing to prevent the victim who has already reported a crime to the police from demanding settlement; it has been suggested, however, that settlement of the extra legal variety is far more common. Note, supra note 13, 39 CoLum. L. REv. at 1186, 1190-92.

19 See, e.g., Schafer, Restitution to Victims of Crime-An Old Correctional Aim Modernized, 50 MINN. L. REv, 243 (1965).

20 CAL. WeLFARE \& INST'NS CODE § 11211. 
the financial irresponsibility of criminals as a class, ${ }^{21}$ it seems unlikely that the fines collected will provide more than token aid for victims. ${ }^{22}$ More ambitious schemes for restitution have been advocated from time to time by penologists who suggest extensive prison reform by which prison earnings might be increased and applied to the needs of victims or a period of probation after sentence is served during which money might be earned to pay victims. ${ }^{23}$ Perhaps because these schemes are so unlikely of adoption, the merits of reparation as a means of rehabilitating the offender have received little discussion, ${ }^{24}$ it is possible, however, that the incentives for prisoners to learn new skills and for parolees to seek jobs would be weakened by the diversion of their earnings to victims unless a carefully administered plan comparable to chapter XIII of the Bankruptcy Act were established. ${ }^{25}$

The British government's conclusion that a compensation plan based

21 In recognition that the hardships resulting from imposition of fines on impoverished offenders would be borne by their families or eventually by the state, the law exempts from the payment of fines those criminals whose families would become welfare charges if a fine were levied. Ibid.

22 Eligibility for payments will be determined by criteria substantially similar to those for aid to dependent children, and benefits will be paid on that scale. The total amount payable under the program in its first year is limited to $\$ 100,000$. Ibid. See Note, California Enacts Legislation To Aid Victims of Violence, 18 STAN. L. REv. 266, $268-73$ (1965).

23 The penologists' proposals for restitution stem from a concept of reparation as a technique of rehabilitation. A British White Paper on penal policy suggested: "It may well be that our penal system would not only provide a more effective deterrent to crime, but would also find a greater moral value, if the concept of personal reparation to the victim were added to the concepts of deterrence by punishment and of reform by training." Penal Practice in a Changing Society, CMND. 645, at 7 (1959). See also Eglash, Creative Restitution: A Broader Meaning for an Old Term, 48 J. CRIM. L., C. \& P.S. 619 (1958); Schafer, supra note 19, at 251-53. Restitution has a long history in penal thought. See Childres, Compensation for Criminally Inflicted Personal Injury, 39 N.Y.U.L. REv. 444, 448-55 (1964); Silving, supra note 14, at 239-46.

24 Professor Wolfgang has observed, however, that the value of reparation as an instrument of rehabilitation would be greatest in cases of first offenders or juvenile delinquents who share to some extent the values of the culture which they have offended; the professional criminal or the psychopath might be less amenable to the influence of reparation. Wolfgang, Victim Compensation in Crimes of Personal Violence: Interdisciplinary Problems in Criminology, in PAPers of the AMerican Society of Criminology 1964, at 169, 173-74.

25 Chapter XIII of the Bankruptcy Act, Il U.S.C. $\$ \$ 1001-86$ (1964), allows a wage earner, with the consent of court and creditors, to pay his debts out of future earnings while protected from garnishments and wage attachments. A court-appointed trustee receives the debtor's salary checks as they are earned, distributing a portion, usually around twenty per cent, to creditors. A chapter XIII plan is intended to save the debtor from the stigma of formal bankruptcy; much of its success depends on his sincere desire to meet his obligations and on the counselling made available to him. See generally Riley, Chapter XIIIs in the Mradison Bankruptcy Court, $37 \mathrm{~J}$. NAT'L Ass'N OF REFEREES IN BANkruptcy 55 (1963); Note, Wage Earners' Plans-Chapter XIII, 45 MLARquetre L. Rev. 582 (1962). 
on restitution was impracticable absent major penal reform ${ }^{26}$ seems applicable to this country. Although it may be sensible to exact from prosperous criminals whatever restitution they can supply, ${ }^{27}$ it is clear that restitution will fall short of providing adequate compensation for victims. State compensation thus seems necessary if that objective is to be accomplished, and it may be argued that the state, because it impairs the victim's private remedy to a certain extent by interposing criminal sanctions, may have some obligation to provide an alternative source of assistance.

\section{B. Liability of the State}

In describing the victim of crime as one "denied the protection of the laws," 28 Mr. Justice Goldberg has expressed the view of some recent commentators ${ }^{29}$ that because the state has a duty to protect its citizens it has a corresponding obligation to assist them when that duty is not fulfilled. An early protagonist of this view was Jeremy Bentham who, taking exception to the traditional understanding that law enforcement, like criminal prosecution, is properly unconcerned with the individual interests of victims, ${ }^{30}$ argued instead that enforcement of the criminal law is a guarantee of the security of the individual as well as of the community. ${ }^{31}$ Stressing that the state undertakes to maintain conditions

26 The Working Party, although concluding that a scheme based solely on restitution was unfeasible, nevertheless thought some provision for recovery from the offender desirable. CMnd. 1406, at 5. When the Government announced its compensation plan, however, it declared that restitution was impracticable in a majority of cases. CMND. 2323, at 7. The scheme's administrators have reached the same conclusion. Criminal Injuries Compensation Board: First Report and Accounts, CMND. 2782, at 6 (1965).

27 The British plan does not disturb the existing framework of tort liability, although the victim who recovers a civil judgment must repay the state up to the amount previously received in compensation. CMND. 2323, at 7. Under the New Zealand law, the state may recover from the offender if payments can be made without detriment to his family or his own rehabilitation. N.Z. Pub. Act $134 \S 23$. One federal proposal authorizes the compensation authority to bring a civil action against the offender to recover up to the amount of compensation paid. S. $2155 \S 401$. See generally Rothstein, State Compensation for Criminally Inflicted Injuries, 44 TEXAs L. REv. 38, $47-48$ (1965).

28 "The victim of a robbery or an assault has been denied the 'protection' of the laws in a very real sense, and society should assume some responsibility for making him whole." Goldberg, Equality and Governmental Action, 39 N.Y.U.L. REv. 205, 224 (1964).

29 See, e.g., Childres, supra note 23, 39 N.Y.U.L. REv. at 455. Fry, supra note 4, at 193.

30 E.g., Mueller's argument that crime prevention is the historical goal of the criminal law and that improved law enforcement, rather than compensation, is the proper form of intervention on behalf of victims. Mueller, supra note 15, at 221-29. He fears that compensation would lessen public interest in efficient law enforcement. $I d$. at 231. Similar fears have been expressed by Bruen, Controlling Violence v. Compensating Victims, 50 A.B.A.J. 855 (1964); Inbau, Comment on the Proposal, Compensation for Victims of Criminal Violence: A Round Table, 8 J. PuB. L. 201, 202-03 (1959).

31 Bentham, THEORY OF Legislation 317-18 (1864). 
of public safety and encourages citizens to rely on it for protection, ${ }^{32}$ Bentham suggested that the costs of failures of police protection as well as the costs of providing it should be borne by the state and thus ultimately shared by the community as a whole. ${ }^{33}$

Despite early espousal by Bentham, the notion that the state has an obligation to insulate its citizens from the consequences of crime has failed to win legal acceptance. Its rejection may stem in part from a general reluctance to impose liability on any agency for the wrongful acts of others, ${ }^{34}$ and perhaps also from doubts that the state does in fact undertake to provide more than a general condition of public order. ${ }^{35}$ Many crimes are not within the state's power to prevent, as they are committed in places where the police have no right to $\mathrm{be}^{\mathbf{3 6}}$ or by persons whom they have no ground to suspect. If the rejection of state liability also reflects a desire to protect public funds from depletion, recent legislation ${ }^{37}$ indicates that despite erosion of sovereign immunity

32 "Has a crime been committed? Those who have suffered by it, either in their person or in their fortune, are left to their evil condition. The society which they have contributed to maintain, and which ought to protect them, owes them, however, an indemnity, when its protection has not been effectual." I WORKS OF JEREMY BENTHAM 589 (Limited ed. 1962), cited in Childres, supra note 23, 39 N.Y.U.L. REv. at 446.

33 To a considerable degree Bentham's discussion anticipates modern theories of risk spreading and enterprise liability. See BenthaMr, TheORY OF LEGISLATION, 317-30 (1864).

34 In a related context, however, absolute liability has been imposed for reasons of public policy. Many states have statutes which permit a person whose property, and in some states person as well, is injured by rioters to recover damages from the town or county where the riot occurred. The Illinois Mob Violence Act, now ILr. REv. STAT. ch. 24, \$ 1-4-8 (Supp. 1965), was held a constitutional exercise of the state's police power by the Supreme Court on the theory that the state which creates municipal corporations delegates to them the responsibility of maintaining public order and may enforce that obligation by imposing sanctions on the community which participates or tolerates mob disorder. City of Chicago v. Sturges, 222 U.S. 313, 323 (1911); cf. Note, Municipal Tort Liability: Statutory Liability of Municipalities for Damage Caused by Mobs and Riots, 50 CoRNELL L.Q. 699 (1965). See also Slaton v. City of Chicago, 8 Ill. App. 2d 47, 58 (1955); Note, Communal Liability for Mob Violence, 49 HARv. L. REv. 1962 (1936).

35 This objection was expressed by the British Working Party: "[T]here is a distinction between compensation for the consequences of civil riot, which the forces of law and order may be expected to prevent, and compensation for individual acts of personal violence, which can never be entirely prevented. ... [1]t does not follow that the State has assumed the duty of protecting [its citizens] . . everywhere. ... [T] he most it has done is to create an assumption that it will provide a general condition of civil peace." CMND. 1406, at 7 .

36 Nearly one-third of all criminal homicides occur among family members in the home. FBI, UNIFORM CrIME REPORTs-1964, at 7. See also note 90 infra and accompanying text.

37 See, e.g., Illinois' recently enacted municipal tort liability legislation which contains a deliberate effort to forestall the development of liability for failure of police protection: "Neither a local public entity nor a public employee is liable for failure to establish a police department or otherwise provide police protection service or, if police protection is provided, for failure to provide adequate police protection or service, failure to prevent 
in other areas there is to be no accompanying recognition of liability for failures of police protection..$^{38}$ Nor do expressions of legislative ${ }^{39}$ and judicial concern ${ }^{40}$ for the Good Samaritan constitute acceptance of a state liability to victims of crime: ${ }^{41}$ because the Good Samaritan's claim, unlike that of most victims, is derived from the performance of a public service, the obligation of the public to indemnify him has peculiar overtones of reciprocity and is further buttressed by a public interest in encouraging similar conduct on the part of others. ${ }^{42}$

the commission of crimes and failure to apprehend criminals." IrL. REv. STAT. ch. 85, § 4-102 (Supp. 1965). In California the enactment of tort liability legislation was accompanied by repeal of the state's long-standing mob violence law. Cal. Stats., ch. 1681, $\S 18$ (1963), repealing CAL. Gov'T CoDE $\S \S 50140-45$.

38 The trend toward imposition of liability for negligent performance of proprietary functions has not been accompanied by liability for negligence in performing governmental functions such as police protection. Covey, supra note 13, at 393-94; James, Tort Liability of Governmental Units and Their Officers, 22 U. CHr. L. Rev. 610, 622-29 (1955).

39 Cal. Penal, Code §§ 13600-03; New York, N.Y., Admin. Code § 67-3.2 (1965). These statutes supplement a long-recognized statutory duty to indemnify a person injured while responding to a policeman's request for assistance. E.g., ILL. REv. STAT. ch. 38, § 31-8 (1964) (misdemeanor to fail unreasonably to come to the aid of a peace officer when requested by him to do so); Ill. Rev. Stat. ch. 24, \& 1-4-6 (1964) (provision for indemnity).

40 In the leading case, Schuster v. City of New York, 5 N.Y.2d 75, 154 N.E.2d 534 (1958), the survivor of a murdered police informer brought an action for wrongful death against New York City, alleging that the police had taken inadequate measures to safeguard the decedent. The court held that the complaint stated a cause of action on the ground that "the public (acting in this instance through the City of New York) owes a special duty to use reasonable care for the protection of persons who have collaborated with it in the arrest or prosecution of criminals, once it reasonably appears that they are in danger due to their collaboration." Id. at 80-81, 154 N.E.2d at 537. Commentators were in agreement that the special duty rationale of the Schuster case, while it appeared a radical extension of state liability, was in fact a narrow one limited to the particular fact situation of the case. See 59 Colum. L. Rev. 487 (1959); 72 Harv. L. Rev. 1386 (1959); 57 Mich. L. Rev. 917 (1959).

41 The California and New York City Good Samaritan laws cited note 39 supra fall short of a recognition of state liability. Under the New York City law, the applicant is permitted to apply to the city Board of Estimate for an award; the statute expressly provides, however, that awards are ex gratia and within the discretion of the Board. New YoRK, N.Y., ADMIN. CODE \$ 67-3.2 (1965). Under the California law, the Good Samaritan must seek an award from the state Board of Control, which is to hold a hearing on the claim and the recommendations of law enforcement agencies. If satisfied that the claim is valid the Board must then recommend to the legislature that an appropriation be made to indemnify the claimant. CAL. Penal Code \$\$ 13600-03. It has been suggested that this law does not impose liability on the state but merely institutionalizes a procedure for bringing a bill for private relief. Note, supra note 22, 18 STAN. L. REv. at 267-68.

42 As to the treatment of the Good Samaritan in a scheme which covers victims generally, see JUSTICE REPORT 11-12, suggesting such persons be compensated for any injuries sustained in an attempt to apprehend a criminal. The British plan adopted this approach. CMND. 2323, at 5. The other plans, however, do not distinguish the Good Samaritan from other victims and would presumably compensate him only for injuries inflicted by the criminal. 
The possibility of compensation based on the duty to protect principle is not foreclosed since the scope of state liability could be expanded by statute. Not only does that possibility appear remote, however, but such a theory has overly broad implications. Perhaps aware that liability predicated on a failure to exercise the myriad regulatory and protective functions of today's government would be so broad as to require a fundamental reconsideration of the role of the government in their performance, most proponents of compensation have preferred to regard the duty to protect as an argument for social legislation on behalf of the victim rather than as a basis of legal liability. ${ }^{43}$

\section{Social Welfare}

Much support for compensation has come from those who regard it, like unemployment insurance or old-age benefits, as an aspect of a general social responsibility to alleviate certain kinds of misfortune. ${ }^{44}$ Public intervention on behalf of the victim of crime is appropriate, it is argued, both because distribution of the costs of crime among members of the community as a whole is preferable as a matter of social efficiency to the present system of relying upon private initiatives to move the loss, ${ }^{45}$ and because a rudimentary sense of justice requires that compensation be provided. ${ }^{46}$

It has been argued that, apart from considerations of fairness, compensation would be the best way to distribute the costs of crime because it would spread a risk to which each member of the community is exposed throughout the entire group, thereby ensuring each individual protection against unexpected misfortune at a very small cost to him.47 Compensation financed from general tax revenues involves more than simple risk spreading, however: because crime rates vary substantially among racial, cultural, and economic groups, ${ }^{48}$ it is apparent that every citizen does not run an equal risk of becoming a victim of violence and that compensation would inevitably redistribute the costs of crime from some groups which at present bear a heavy portion of those costs to others on which they fall more lightly. Professor Childres' sugges-

43 See notes 53-57 infra and accompanying text.

44 See, e.g., Childres, supra note 23, 39 N.Y.U.L. Rev. at 457; Fry, supra note 4, at 191-94; Yarborough, S. 2155 of the Eighty-Ninth Congress-the Criminal Injuries Compensation Act, 50 MinN L. Rev. 255 (1965).

45 See notes 47-52 infra and accompanying text.

46 See notes 53-57 infra and accompanying text.

47 Fry, supra note 4, at 192-93.

48 Lower class Negroes, for example, are more likely to be victims of violence than are middle class whites. According to the FBI, more than half the persons murdered in 1964 were Negro, as were more than half the persons arrested for murder. FBI, UNIForM CRIME REPORTS-1964, at 7 . 
tion that compensation is necessary because many victims cannot afford private insurance ${ }^{49}$ implies a similar redistribution. Although little evidence has been adduced as to the extent to which victims of crime do in fact rely on private insurance to absorb their losses, ${ }^{50}$ even an opponent of compensation concedes such defects in private insurance as high premiums, low benefits for disability, and policy exceptions which sometimes deny benefits to victims of crime. ${ }^{51}$ If, as seems likely, adequate low cost private insurance is unavailable to many persons, particularly to those who are most likely to be victims of crime, social insurance may be an appropriate method of financing protection in accordance with the ability to pay and thus of subsidizing the poor victim. ${ }^{52}$

The basis of any redistribution scheme, and probably of all compensation plans, is a charitable impulse to assist those who suffer misfortune. Recognition of the needs of the victim of crime is not unfair to victims of other kinds of misfortune as it does not detract from their claims for assistance; in one view, indeed, the extent to which other groups are provided for makes the case for the victim of crime more compelling. ${ }^{53}$ Nonetheless, the fairness of compensating victims of crime must be measured against the fairness of imposing their losses on others. While the burgeoning of social legislation in other areas has deprived the traditional argument that one not at fault should not be required to insure others against their misfortunes, ${ }^{54}$ of much of its

49 Childres, supra note 23,39 N.Y.U.L. REv. at 457.

50 But see Starrs, A Modest Proposal To Insure Justice for Victims of Crime, 50 Mins. L. REv. 285, 291-94 (1965). The number of individuals who carry some form of life, medical, disability, or other personal insurance is, as he observes, very large; he offers no estimate, however, as to the number of persons who presently receive medical care at public expense. Starrs himself questions the adequacy of private insurance benefits. Id. at 301-09. See also Mueller, supra note 15, at 236.

51 Starrs, supra note 50, at 301-09. Fis assumption that insurance companies could afford to substantially increase benefits while at the same time lowering premiums is unsubstantiated.

52 In a federal program financed from general taxation, the progressive structure of the income tax would operate in theory to shift the costs of premiums more heavily onto wealthier taxpayers. Gf. Blum \& Kalven, Private Law Perspectives on a Public Law Problem: Auto Compensation Plans 83 (1965). To the extent that the tax structure were regressive, however, as state systems based on property and sales taxes are generally conceded to be, the redistributive effect would be nullified. In a compensation plan financed on a contributory basis, each taxpayer making an equal contribution, no redistributive effect would occur except that which would result from forcing low-risk contributors to pay a premium equal to that paid by high-risk contributors. The possibility is of little practical significance, however, as the schemes are too small in scale to merit the administrative costs of collecting a separate tax.

53 See, e.g., Yarborough, supra note 44, at 257. Contra, Inbau, supra note 30, at 203.

54 E.g., Miller's view that the assumption of public responsibility for victims of crime cannot be justified because the public as a whole is not to blame for the victim's losses 
force, the "atomizing of the liability question into insurance premiums should not be permitted to cause the liability issue to evaporate."55 Proponents of compensation have asserted that the society as a whole has a particular obligation to the victim of crime because it has failed to protect him from criminal injury and, in addition, has impaired his potential civil remedy against the offender; ${ }^{50}$ in addition, it has been asserted that society by tolerating the conditions which cause crime incurs some responsibility for its consequences. ${ }^{57}$ These arguments, generally deemed insufficient bases for imposing legal liability on the state, have instead been relied upon to justify an expression of public sympathy for the victim of crime $e^{58}$ and are thus incorporated into the case for social legislation on his behalf.

A social welfare approach which regards compensation as an act of charity justified by a sense of obligation toward the victim has been accepted as the foundation of most of the plans which have been enacted or proposed.59 That approach seems a satisfactory one; more dubious, however, is the tendency of the plans to depart from the "payment as a matter of right" philosophy of social insurance and to provide compensation as a public bounty or gratuity ${ }^{60}$ Thus, the British decla-

and is not a group so related to the primary wrongdoers as to justify the imposition of liability. Miller, Comment on the Proposal, Compensation for Victims of Criminal Violence: A Round Table, 8 J. Pus. L. 203, 205-09 (1959). He distinguishes compensation from public welfare programs, however, on the ground that the latter function on the basis of

- need regardless of fault and are of a minimal or subsistence nature, whereas compensation is redress for a wrongful act. $I d$. at 207.

65 BLUM \& KALveN, op. cit. supra note 52, at 22.

56 See CmNd. 1406, at 7-8; Childres, supra note 23, 39 N.Y.U.L. Rev. at 455; Fry, Justice for Victims, The Observer (London), July 7, 1957, p. 8, col. 2, reprinted in Compensation for Victims of Criminal Violence: A Round Table, 8 J. PUB. L. 191, 193 (1959); Yarborough, supra note 44 , at 256.

57 E.g., Silving, Comment on the Proposal, Compensation for Victims of Criminal Violence: A Round Table, 8 J. PuB. L. 236, 252 (1959). It is perhaps unnecessary to place the blame for the victim's losses entirely on society, as a lesser degree of accountability might suffice to justify acceptance of some responsibility. See Childres, supra note 28, 39 N.Y.U.L. REv. at $456 \cdot 57$.

58 See authorities cited note 56 supra.

59 The British Government in announcing the compensation plan stated that: "Compensation will be paid ex gratia. The Government do not accept that the state is liable for injuries caused to people by the acts of others. The public does, however, feel a sense of responsibility for and sympathy with the innocent victim, and it is right that this feeling should find practical expression in the provision of compensation on behalf of the community." CMND. 2323, at 4. Similar views were entertained in New Zealand. Cameron, Compensation for Victims of Crime: The New Zealand Experiment, 12 J. Pub. L. 367, 369-70 (1963). Senator Yarborough also accepts the social welfare rationale as the basis of his plan. Yarborough, supra note 44, at 256.

60 Public payments were generally considered gratuities in the early stages of state welfare legislation. See Mandelker, Judicial Review in General Assistance, 6 J. PuB. L. 100 (1957); Reich, Individual Rights and Social Welfare: The Emerging Legal Issues, 74 YALE 
ration that compensation would be paid "ex gratia" 61 is reflected in the New Zealand law and in the federal proposals which also make the payment of compensation discretionary with administrative authorities and foreclose judicial review. ${ }^{62}$ Arguably, if compensation is in fact a gesture of public sympathy there should be no objection to awarding it on a discretionary basis, particularly when the discretionary framework offers advantages of flexibility and freedom to experiment. ${ }^{63}$ The absence of an obligation to undertake such a scheme should not, however, be confused with absence of a legal right to receive benefits when one has been granted by the legislature to eligible claimants. ${ }^{64}$ Inas-

L.J. 1245 (1965). "Payment as a matter of right" became a central principle of social legislation during the 1930's in an effort to depart from the traditional idea that public payments were a form of charity. See, e.g., Smith, Public Assistance as a Social Obligation, 63 HARv. L. REv. 266, 268 (1949); tenBroek \& Wilson, Public Assistance and Social Insurance -A Normative Evaluation, I U.C.L.A.L. REv. 237, 238-44 (1954); Note, Charity Versus Social Insurance in Unemployment Compensation Laws, 73 YALE L.J. 357, 359 (1963). The Social Security laws, for example, provide for a complex system of administrative appeals and for judicial review of findings by the Secretary of Health, Education, and Welfare. See Vasconcelles, What Every Lawyer Should Know About Social Security, 50 ILL. B.J. 540, 543-47 (1962).

Veteran's benefits and the Federal Employees Compensation Act, on the other hand, expressly preclude judicial review; their constitutionality has been upheld on the theory that such payments are "mere gratuities" to which no legal right attaches and which Congress may make available as it chooses. See, e.g., Calderon v. Tobin, 187 F.2d 514 (D.C. Cir. 1951) (F.E.C.A.); Van Horne v. Hines, 122 F.2d 207 (D.C. Cir. 1941) (veteran's benefits).

61 CMND. 2323, at 4; see note 59 supra. Adoption of the ex gratia approach was in part an aspect of the Government's decision to begin the scheme on a nonstatutory basis, in the hope that a period of experimentation would be followed by legislation. See Note, Great Britain Approves Compensation Program for Victims of Violence, 78 HARv. L. REv. 1683,1686 (1965). The Board has taken the view, however, that compensation should be paid to all claimants who fall within the scheme. Criminal Injuries Compensation Board, First Report and Accounts, CMND. 2782, at 4 (1965).

62 E.g., H.R. 11818, 89th Cong., Ist Sess. $\$ 301$ (a) (1965) ("In any case in which a person is injured or killed by any act ... the Commission may, in its discretion, . . . order the payment of compensation. . . ."); H.R. 11818, 89th Cong., 1st Sess. § 207 (1965) (providing that the agency's decisions are to be final). The bills appear to have been drafted to satisfy the conditions of unreviewability under $\S 10$ of the Administrative Procedure Act, which provides: "Except so far as (1) statutes preclude judicial review or (2) agency action is by law committed to agency discretion. . ." 60 Stat. 243 (1946), 5 U.S.C. \$ 1009 (1964). Statutes which, like the proposals, merely provide for finality are seldom held to manifest a clear intent to exclude review altogether, Jaffe, The Right to Judicial Review II, 71 HARv. L. REv. 769, 770 (1958), but where the agency's action is expressly committed to agency discretion, review may be precluded for that reason. Id. at 774-78; 4 DAvis, ADMinistrative LAw Treatise $\$ 28.16$ (1958). Thus, although denial of an award would not be reviewable on substantive grounds, procedural matters not expressly committed to the commission's discretion might be.

63 These advantages were thought important in Britain, CMND. 2323, at 4, and in New Zealand, Cameron, supra note 59, at 372-73.

64 See Rothstein, State Compensation for Criminally Inflicted Injuries, 44 TEXas $\mathrm{L}$. REv. 38, 49 (1965). 
much as charitable motives also underlie much of the social legislation of the present day, the notion that public payments for victims of crime are a gratuity seems oddly anachronistic.

\section{The Scope and Extent of Compensation}

The social welfare principles underlying most compensation plans permit substantial flexibility in determining their scope and extent. Before a program can be enacted, the criminal acts for which compensation is to be awarded and the victims who will qualify for assistance must be enumerated, and the amount of damages payable for different categories of injury must be determined. Despite the considerable similarities among the plans, ${ }^{65}$ solutions to these problems have not yet evolved, and there remain a number of areas in which significant variations may be found.

\section{A. What Crimes Should Be Compensated?}

Recent interest in compensation has focused on the victim who suffers personal injury as a result of a crime of violence. ${ }^{66}$ If social ivelfare reasoning is chosen to support compensation, ${ }^{67}$ there seems to be no compelling reason for not giving effect to what appears to be a widely held feeling of special concern for physical injury. Com. mentators have justified the exclusion of crimes against property from the schemes on the ground that victims who suffer physical injury are in greater need of assistance both because injury to the person may be a catastrophe of greater magnitude to the individual than loss of prop-

65 The similarity is in part a measure of the influence of the British and New Zealand plans, after the latter of which the bill introduced by Senator Yarborough is modeled. Yarborough, supra note 44, at 258.

66 For a rare exception, see the suggestion of a plan including property damage in testimony of Dr. Seward Reese, Dean of the College of Law, Willamette University, before the Senate Judiciary Committee of the Oregon Legislature, March 25, 1965. For the usual view, see, e.g., Childres, supra note 23, 39 N.X.U.L. REv. at 460.

67 Since a state's duty to protect its citizens would extend to their property as well as their persons, the distinction seems difficult to justify under a state liability argument; indeed, the British Working Party termed the duty to protect principle "dangerous, because acceptance of public liability for offenses against the person could be the basis for a demand for acceptance of liability for all offenses against property." CMND. 1406, at 7 . Because the offender's existing obligation to make restitution is not limited to personal injuries the exclusion of property loss in a plan based on that principle seems arbitrary; it might be argued, however, that when the state intervenes to collect restitution it may limit its assistance to those who are most in need. Thus California's compensation law provides for the levying of fines on offenders convicted of crimes of violence and for payments to victims of violence, but not on offenders convicted of other crimes or to victims who suffer other kinds of loss. CaL. WELFare \& INST'NS CODE § 11211. 
erty ${ }^{68}$ and because private insurance against loss of property is widespread. ${ }^{99}$ Moreover, a scheme which included damage to property would be far more complex and costly than one limited to personal injuries. ${ }^{70}$

Of crimes which may result in personal injury, the plans have without exception excluded regulatory and negligent offenses. ${ }^{71}$ Little justification has been offered for this exclusion beyond an assertion that such crimes are not violent, ${ }^{72}$ although it may also be suggested that in areas where civil recovery is more readily available there is less need for compensation. There has been some confusion, however, as to whether injuries resulting from all crimes which require criminal intent should be compensated, or only those which result from crimes which are classified as violent. The British scheme requires that injury be attributable to a criminal offense involving the use of force, ${ }^{73}$ while the New Zealand law includes a schedule enumerating solely violent offenses against the person; ${ }^{74}$ one federal proposal, however, adopts a broader view, making compensation payable for injury resulting from any offense which is a felony under state or federal law. ${ }^{75}$ One writer who favors such a formulation has observed that, while the problem would arise infrequently, distinctions between violent and non-violent

68 See, e.g., JUstice REPORT 7; Childres, supra note 23, 39 N.Y.U.L. REv. 460; Yarborough, supra note 44 , at 261.

69 See authorities cited note 68 supra. Although not all owners of property can afford to insure it, it has been asserted that the present system of property insurance is adequate whatever the deficiencies of insurance against personal injuries Starrs, supra note 50, at 294-96. The danger that awarding compensation for property damage would encourage fraudulent claims has also troubled commentators. Miss Fry suggested that while few people would wound themselves to obtain a modest compensation, the expense of fraudulent property claims would be so great as to make compensation for property loss financially prohibitive. Fry, supra note 56, at 192-93. Miss Fry's point has merit in that the state, unlike private insurers, would be unable to meet the costs of fraudulent claims by passing them on to insureds through higher premiums.

70 The number of claims arising from crime against the person would be small in comparison with those for loss of property. In 1964 the property offenses of burglary, robbery, larceny over $\$ 50$, and auto theft made up $87 \%$ of the "serious offenses" indexed by the FBI. FBI, UNIFORM CRIME REPORTS-1964, at 6.

71 N.Z. Pub. Act 134, Schedule; S. 2155, § 302; H.R. 11818, § 302; CMND. 2323, at 5.

72 CMND. 2323, at 6; Yarborough, supra note 44, at 264.

73 GMND. 2323. at 5.

74 N.Z. Pub. Act 134, Schedule. Such a schedule, which may be a convenient method of defining the scope of a scheme, has been criticized on the ground that it is impossible to foresee all the kinds of crimes from which injury may result. See Rothstein, supra note 64, at $40-41$.

75 H.R. 11818, § 302. Although the Yarborough bill follows the New Zealand law in setting up a schedule of compensable crimes, there apparently is no intent to confine compensation to crimes of violence. "[W]e presume that any type of crime producing a personal injury is included as an assault, and that classification would entitle the victim to an award." Yarborough, supra note 44, at 263. 
crimes are not always easy to draw and are somewhat arbitrary for the purposes of a social welfare program whose primary concern is injury to the victim..$^{76}$

If it is thought necessary to confine the scope of compensation more narrowly, ${ }^{77}$ limitations might be imposed in terms of the degree of injury sustained rather than its source. The British plan and one federal proposal accomplish this purpose by specifying that injury in order to be compensable must be sufficiently serious to merit an award in excess of a certain amount. ${ }^{78}$ Assuming that the threshold amount were set at a low level, such a requirement would entail minimum hardship to victims and might result in substantial savings in the costs of investigating and paying large numbers of small claims.

The scheme might be further narrowed by excluding some specific offenses, particularly such non-violent sexual offenses as indecent exposure and obscene conduct, which do not usually give rise to physical, by contrast with mental, injury. ${ }^{79}$ A further consideration justifying their exclusion is that, like other sexual offenses, they present special administrative problems; the commission of such crimes and the degree of the victim's complicity are difficult to prove, and damages hard to measure. ${ }^{80}$ While public opinion in Britain demanded that compensation be provided for some sexual offenses, ${ }^{81}$ and might do so in this country as well, the inclusion of only forcible sexual offenses might help to contain these difficulties. ${ }^{82}$

The awarding of compensation should not necessarily be contingent on a judicial finding that an act was illegal within the meaning of the criminal law. The British, New Zealand, and federal plans properly allow a victim to receive compensation whether or not the offender

76 Rothstein, supra note 64 , at $40-41$.

77 See, e.g., Childres, Compensation for Criminally Inflicted Personal Injury, 39 N.Y.U.L. REv. 444, 459.61 (1964).

78 The Green bill requires that damages exceed $\$ 300$. H.R. 11818, § 304(b). Under the British plan, compensation is awarded only for injuries for which" an award of over three weeks loss of earnings or $£ 50$ would be paid. CMND. 2323, at 5 .

70 These offenses were included in S. 2155, \& $302(7)$, (8) for the following reason: "If, for example, such acts produced extreme mental and nervous shock in an elderly lady of tender sensibilities, the commission should be authorized to exercise its compassionate discretion." Yarborough, supra note 44, at 213.

80 See Justice REPORT 7-8, 10; Weihofen, Comment on the Proposal, Compensation for Victims of Criminal Violence: A Round Table, 8 J. PUB. L. 209, 210-11 (1959).

81 CMND. 2323, at 6.

82 See Justice Report 7-8, 10. See also Letter From Professor Norval Morris to Senator Ralph W. Yarborough, Aug. 21, 1965, copy on file at The University of Chicago Law Review office, discussing the particular problems raised by sexual offenses and suggesting that it may be "wiser at this stage . . to exclude those offenses unless there is other grave physical harm caused by their commission." 
has been apprehended, convicted, or even acquitted. ${ }^{83}$ The offender's lack of capacity to form criminal intent for such reasons as insanity, drunkenness, or infancy is also irrelevant as to whether a compensable offense was perpetrated on the victim, since these special defenses represent merely a social judgment that an act which would otherwise be criminal should be excused.84 More difficult questions arise as to the standard of causation which should be applied to determine whether the victim's injury was "a result of" 85 or "directly attributable" 86 to a criminal offense. While some concept of remoteness is necessary if a distinction between criminal and accidental injuries is to be preserved, one commentator has urged that compensation plans formulate their own standards rather than apply the tests appropriate for the criminal law. ${ }^{87}$

\section{B. Determining Which Victims Should Be Eligible}

None of the justifications for shifting losses from the victim of crime extend to the person who is responsible for his own injuries, ${ }^{88}$ and all of the plans contain provisions intended to prevent such victims from receiving compensation. ${ }^{89}$ These provisions do not, however, supply

83 N.Z. Pub. Act 134, § 17(6); S. 2155, § 301(f); H.R. 11818, § 301(f); CMND. 2323, at 5.

84 But see Case No. 119, Criminal Injuries Board Awards-April 1965, 1965 CRIM. L. REv. (Eng.) 452 (compensation denied to child hit by rock on ground that assailant below age of criminal responsibility). Other plans avoid that result by providing that the offender's lack of capacity to form criminal intent should be disregarded. N.Z. Pub. Act 134, § 17(2); S. 2155, § 301(c); H.R. 11818, § 301(c). See Rothstein, supra note 64, at 39-47.

85 H.R. 11818, § 301(e)(2); S. 2155, § 301(e)(2). Cf. N.Z. Pub. Act 134 which, as originally drafted, made compensation payable for injuries "resulting" from a crime; that language was altered to make compensation payable for injury or death "by" a crime in order to limit more clearly the scheme to immediate victims upon whom crimes were perpetrated and to avoid difficulties of causation, although there is doubt as to whether that effect has been achieved. Cameron, supra note 59, at 371-72.

86 CMND. 2323, at 5. Compare Case No. B.6, Criminal Injuries Compensation AwardsMay 1965, 1965 Crim. L. Rev. (Eng.) 502, 506 (compensation denied a man who, knocked down by another, fell and hit his head against a radiator), with Case No. A.48, Criminal Injuries Compensation Awards-June 1965, 1965 Crim. L. REv. (Eng.) 567, 569 (compensation awarded to a woman injured when a gate, removed from its hinges by boys, fell on her).

87 Rothstein, supra note 64 , at $40-44$.

88 The victim to whom responsibility attaches cannot be said to have relied on the state for protection, and it is arguable that the state should not assist him in collecting restitution from the offender. The culpable victim might be excluded from a plan based on a social welfare rationale on the ground that he is not a proper object of social sympathy and that one who by wronging or provoking another creates a risk of injury to himself has no claim for indemnity from other members of the community who do not engage in such conduct. See CMND. 1406, at 11-12; notes 101-02 infra and accompanying text.

89 Only the California plan omits a provision disqualifying the culpable victim. CAL. Welfare \& INST'NS CoDE $\$ 11211$. For provisions of the other plans, see notes 93, 104-05 infra and accompanying text. 
criteria to be applied in appraising the conduct of victims, perhaps because there is considerable uncertainty as to what those criteria should be.

Although much support for compensation has been generated by the image of the victim as a hapless citizen asaulted by a stranger on a dark street, a substantial majority of crimes of violence arise from close personal relationships ${ }^{90}$ and are, in the view of one critic of compensation, often the product of the personality of the victim as well as of the offender. ${ }^{91}$ That circumstance should not be equated with fault on the victim's part, and the implication that crimes motivated by personal antagonism are for that reason outside the sphere of public responsibility is of doubtful validity. ${ }^{92}$ Nonetheless, it might be argued that the greater potential of victim involvement in personal crimes and the difficulties involved in establishing its presence are sufficient to warrant the exclusion of such victims on a categorical basis. Thus, some compensation plans have excluded victims who are relatives of the offender's family or members of his household from receiving awards..$^{93}$ Although this exclusion has been attributed to the difficulties of determining the facts surrounding such incidents and to a desire to prevent

90 While crimes against property are generally directed at the possessions of strangers, crimes of violence are typically provoked by personal relationships. According to the FBI, killings within the family constituted $31 \%$ of murders in 1964 . Murders "outside the family unit, usually altercations between acquaintances" amounted to $49 \%$ of the total; $22 \%$ of these arose from lovers' quarrels or romantic entanglements and $17 \%$ from drinking situations. Only $15 \%$ of the murders in 1964 fell into the felony-murder category while the genesis of the remaining $5 \%$ is unknown. FBI, UNYFORM CRIME REPORTS -1964 , at 7. About two-thirds of aggravated assaults were committed between members of families or acquaintances. $I d$. at 8.

91 Weihofen, asserting the significance of psychological interaction between victim and offender, states that the victim frequently plays the role of an "activating sufferer." Weihofen, supra note 80, at 217.

92 The question whether the existence of personal relationships apart from fault is a proper basis for denying compensation axises most significantly in connection with crimes committed between members of a family. The exclusion of family crimes is perhaps consonant with the duty to protect argument in light of the putative impossibility of a state's preventing all such crimes, and probably is not inconsistent with the restitution theory since tort liability does not arise in many such situations. A distinction between family and other personal relationships seems less appropriate, however, in a plan based on social welfare principles, although there may be some reluctance to intervene in family life by making judgments as to the conduct of its members.

93 The federal proposals exclude "relatives" of the offender or members of his household from compensation, with relatives being broadly defined to include not only spouses and children but also grandparents, aunts and uncles, and others. S. 2155, § 102(5); H.R. 11818 , $\$ 102(5)$. That broad formulation was taken from the New Zealand law, which does not bar such victims from compensation but only from pain and suffering damages. N.Z. Pub. Act 134, § 18. The British plan excludes victims who are members of the offender's household living with him at the time of the crime. CMND. 2323, at 6. 
the offender from benefiting from the victim's award,94 commentators have suggested that these problems, while significant, be surmounted by special provisions for payment and requirements of proof for family crimes rather than by a blanket exclusion..$^{95}$

The controversy over the extent to which victims of crime are responsible for their injuries has not been resolved, ${ }^{96}$ but the perception that culpability attaches to at least some victims is a significant one. As Professor Weihofen has observed, the law makes little allowance for the "tormenting conduct" of victims; ${ }^{97}$ personal motives excuse neither crime nor tort, ${ }^{98}$ and application of the rules of provocation and self defense are sufficiently narrow as to often result in the imposition of liability on the offender despite the victim's aggravating or aggressive behavior. ${ }^{99}$ Weihofen's conclusion that compensation requires a new definition of fault by which to measure the conduct of victims seems correct, inasmuch as the criminal law is concerned with the conduct of the victim only as it affects the culpability of the offender, and the tort law's allocation of loss between victim and offender has no necessary bearing on the allocation between victim and community. ${ }^{100}$ The

94 CMND. 1406, at 12-13. Yarborough, S. 2155 of the Eighty-Ninth Congress-The Criminal Injuries Compensation Act, 50 MINN. L. Rev. 255 (1965).

95 See Justice Report 9-10; Childres, Compensation for Criminally Inflicted Personal Injury, 50 MINN. L. REv. 271, 276-77 (1965).

96 Weihofen and Mueller have put considerable emphasis on the problem of victim "involvement." Weihofen, supra note 80; Mueller, Comment on the Proposal, Compensation for Victims of Criminal Violence: $A$ Round Table, 8 J. PUB. L. 218, 231-32 (1959); Mueller, Compensation for Victims of Crime: Thought Before Action, 50 MINN. L. REv. 213, 214-15 (1965). Frequently reliance is placed upon Wolfgang's study of 588 criminal homicides in Philadelphia which determined that $26 \%$ of the killings were "victim precipitated" in that the victim was the first to "show and use a deadly weapon, to strike a blow in an altercation ... the first to commence the interplay or resort to physical violence." Wolfgang, Victim Precipitated Criminal Homicide, 48 J. Crim. L., G. \& P.S. 1, 3 (1957). Wolgang further concluded that "in many cases the victim has many of the major characteristics of an offender... it is probably only chance which results in one becoming a victim and the other becoming an offender." Id. at 11 .

Mueller considers the evidence sufficient to show that there may be "few non-culpable" victims of crime. Mueller, supra, $8 \mathrm{~J}$. Pub. L. at 231. Childres, however, regards the evidence as demonstrating only that a minority of victims are responsible for their injuries. Childres, supra note 77, 39 N.Y.U.L. REv, at 468-69. See also Childres, supra note 95, 50 MiNN. L. REv. at 272-74.

97 Weihofen, supra note 80 , at 212.

98 Cf. Prosser, TORTS \$\$ 19, 111 (3d ed. 1964).

$99 \mathrm{As}$, for example, where the victim strikes the first blow but the offender retaliates with unreasonable force. Ibid.

100 When the offender is acquitted on grounds of self defense the criminal law provides a de minimis definition of victim involvement because the victim's injuries are not attributable to a criminal offense. In situations where the victim's conduct mitigates rather than excuses the offender from criminal responsibility, as where a murder charge is reduced to manslaughter, however, the law furnishes little guide to the victim's status. 
British Working Party, observing that a person who sustains injury by reason of his character or course of conduct has assumed the risk of criminal injury and is not a proper object of social sympathy, ${ }^{101}$ concluded that compensation should be paid only for "unprovoked assaults upon innocent persons."102 It was nonetheless considered impracticable to appraise provocation and innocence by reference to explicit standards; ${ }^{103}$ the administrative board was instead authorized in broad terms to inquire into the conduct of victims and to take degrees of fault into account when making awards. ${ }^{104}$ The New Zealand and federal plans follow a similar approach, although the federal proposals make no allowance for partial responsibility. ${ }^{105}$

Experience under the British plan suggests that despite their broad power to do so, administrators of the scheme infrequently disqualify victims for fault. Findings of fault are made only in the context of conduct at the time of the incident, ${ }^{106}$ and even then awards are generally reduced rather than denied altogether. ${ }^{107}$ The number of cases in which the victim's conduct has affected his award appears small,108 although this may reflect a decision on the part of culpable victims not to seek compensation as well as the liberal policy of the Board.

Although tort law offers defenses which the offender can raise against the victim's claim, application of these rules may not produce a markedly different result from those of the criminal law, particularly as these rules have in some instances been subordinated to the policy of the criminal law. See Bohlen, Consent as Affecting Civil Liability for Breaches of the Peace, 24 Corum. L. Rev. 819 (1924).

101 "[Crimes of violence] are by no means always committed upon honest persons, and where a particular crime arises directly from the undesirable activities of the victim, his mode of life, and the company he keeps, it could scarcely be argued that the State had any moral obligation to compensate him." GMND. 1406, at 11.

102 Ibid.

$103 \mathrm{Id}$. at 11-12.

104 CMND. 2328, at 6.

105 N.Z. Pub. Act 134, § 19(7)(a); S. 2155 § 301(d); H.R. 11818 § 301(d).

106 In one case the Board resorted to a technicality rather than deny compensation on the basis of past conduct. Case No. H.13, Criminal Injuries Compensation Board, Report, Dec. 31, 1965, at 7 . In that case, compensation was denied to a man shot by an escaped convict with whose wife he had been living. The victim refused to discuss the incident with the police, although his assailant, whose identity was not in doubt, was later apprehended and prosecuted on other charges. The award was denied on the ground that the scheme's requirement that the crime have been reported to the police or have been the subject of criminal prosecution had not been met.

107 A typical decision when the victim willingly engages in a fight is to assess his responsibility at $50 \%$ and to reduce his award accordingly. See (Abstract) Case No. A.3, Criminal Injuries Compensation Awards-May 1965, 1965 CRIM. L. REv. (Eng.) 502, 505.

108 For example, of 74 cases abstracted in the Criminal Law Review in one month, there are only three assessments of partial responsibility and no instances of an award denied outright for reasons of fault. See Criminal Injuries Compensation Awards-May 1965, 1965 CRIM. L. REv. (Eng.) 502-08. 
The slight significance accorded to fault in the British scheme has substantial practical advantages; it is desirable to confine the investigation before awards are made to events surrounding the commission of a crime, as determinations of the circumstances which preceded it would be difficult to make and limits on the scope of inquiry hard to impose. ${ }^{109}$ The British Board's reluctance to apply a standard embracing prior conduct and its allowance for partial responsibility is further suggestive of tension between the objective of confining compensation to "genuine and deserving"110 victims and the social welfare character of the scheme. Eligibility for government benefits is not ordinarily contingent on judgments of character, past associations, and the like; compensation, insofar as it introduces a broad notion of blameworthiness, represents an unusual departure from other social welfare programs which function on the basis of need regardless of fault.

\section{G. The Amount of Damages}

Provisions for the payment of damages vary considerably among the different compensation plans. There is general agreement that the amounts of awards in a tax supported program should be less than jury verdicts in personal injury lawsuits. On the basic question of whether compensation should be paid on a common law pattern or should instead resemble workmen's compensation or social welfare programs there is less disagreement. One federal proposal allows recovery of damages on the common law pattern for the victim's medical and other expenses, past and future loss of earnings, and pain and suffering, subject to a $\$ 25,000$ ceiling on the total award to any one claimant. ${ }^{111}$ The British and New Zealand plans also adopt the common law elements of damage; ${ }^{112}$ the British plan, however, limits awards for loss of earnings to an amount equal to twice the average weekly industrial wage, ${ }^{113}$ and the New Zealand plan imposes ceilings on recovery for

109 As an illustration of the difficulties of including prior conduct within the investigation, consider that $A$ 's claim based on an assault by jealous husband $B$ would require a determination not only as to the circumstances of the assault but also as to whether $A$ had in fact been having an affair with $B$ 's wife. Similarly, one might imagine a claim by the widow of a slain gangster; since it is unlikely that evidence of her husband's criminal activities would be forthcoming, denial of her claim would have to be predicated on her husband's reputation as a gangster.

110 CMND. 1406, at 11.

111 S. 2155, \$\$ 303, 304(b) (the Yarborough bill). The Green bill also imposes a $\$ 25,000$ ceiling on awards, but does not allow recovery for pain and suffering damages. H.R. 11818, §§ 303, 304(b).

112 N.Z. Pub. Act 134, $\S 19(3)$; Cund. 2323, at 6. None of the plans allow the victim to recover punitive damages.

113 CMND. 2323, at 6. In Britain the flat rate, subsistence level benefits of social welfare programs were thought inadequate, Jusmce REPORT 16-17; CMND. 1406, at 14-16, but some 
loss of earnings and for pecuniary loss to dependents which approximate benefits under that country's social security and worker's compensation programs. ${ }^{114}$ These variations in the scale of awards are characteristic of the hybrid nature of the plans; while the social welfare rationale on which they are based would seem to justify considerable departure from common law principles, there has been here as elsewhere an effort to compromise with those principles rather than abandon them altogether.

Under most plans other public payments received by the victim as a result of his injuries are deducted from his award. ${ }^{115}$ These provisions seem justifiable as simple economy measures in the absence of any argument for requiring the state to make double payment for the same injuries. Consideration might also be given to the subtraction of private insurance payments which reduce the victim's need for assistance, on the reasoning that the collateral benefits rule which serves to prevent wrongdoers from escaping full damages by virtue of the prudence of those whom they injure, ${ }^{116}$ has no application to a compensation plan; as the public is not a wrongdoer, there is no reason for departing from the general principle that damages should be compensatory for losses actually incurred. Compensation plans have, however, resisted the deduction of private insurance payments, ${ }^{117}$ perhaps less from a fear that such deductions would discourage the purchase of private insurance ${ }^{118}$ than from a conviction that social insurance available to rich and poor alike is preferable to welfare conceived as charity to the needy. ${ }^{119}$ Recognition that compensation may not absorb all the victim's losses, and that private insurance may be similarly limited, suggests that in many cases private insurance coupled with compensation may not be a double payment but may instead represent a partial contribution from two sources; in such situations, it seems preferable to regard compensation,

degree of standardization was thought necessary: "[A] State scheme which resulted in two persons, because they followed different employments, being paid different amounts in respect of identical injuries ... might be regarded as unfair." CMND. 1406, at 15 .

114 N.Z. Pub. Act 134, \$\$ 19(3)(a), (b); see Cameron, supra note 59, at 374. Cameron considers that scale too low, but states that it was thought politically unfeasible to pay victims of crime at a higher rate than victims of industrial injuries. Id. at 373-74.

115 N.Z. Pub. Act 134, §§ 19(7)(b), (c), (d); S. 2155, § 305(b); H.R. 11818, § 305(b); CMND. 2323 , at 7.

116 Cf. MCCormick, Damages § 90, at 324 (1935).

117 Senator Yarborough indicates, however, that under his bill the commission would have discretionary authority to make such deductions. Yarborough, supra note 94, at 263.

118 See Childres, supra note 77, 39 N.Y.U.L. Rev., at 444 . It seems unlikely, however, that the deduction would impair the purchase of private insurance, as most people probably regard the risk of criminal injury as minimal and do not take it into account when deciding whether or not to purchase medical or life insurance.

119 Cf. Justice RePort 19; CMND. 1406, at 19. 
like social security, as a supplement to, rather than a substitute for, private insurance.

Some writers have suggested that compensation should not include payments for pain and suffering, ${ }^{120}$ which are commonly omitted from workmen's compensation and public programs, on the grounds that such damages are unduly speculative and that it is appropriate for a government plan which cannot shift the victim's entire loss to give priority to economic losses. ${ }^{121}$ In another view, pain and suffering are considered important elements of damage properly included in compensation as opposed to other public programs ${ }^{122}$ on the theory that the public wishes to recognize the particularly unpleasant nature of criminal injury, as well as its financial consequences. ${ }^{123}$ In New Zealand nominal damages for pain and suffering ${ }^{124}$ were retained primarily as a concession to victims of sexual offenses who might have minimal actual damages on which to found a claim. ${ }^{125}$ That reasoning, however, confuses payments for pain with payments for psychic injury which might be compensated as such. ${ }^{126}$ Compensation for the dignitary aspects of criminal injury may be greater in Britain and New Zealand, where free medical care and other public benefits absorb some portion of the victim's financial losses, than in the United States, where awards for medical and other expenses would be larger, and compensation without pain and suffering would not be an empty gesture to most victims. ${ }^{127}$

120 See, e.g., Childres, supra note 95, 50 MrNN. L. Rev. at 278.

$121 \mathrm{Ibid}$. The argument against pain and suffering damages is based in part on the objections to such awards in common law actions. See Jaffe, Damages for Personal Injury: The Impact of Insurance, 18 LAw \& ConTEMP. ProB. 219, 222-35 (1953). For parallel proposals to eliminate such damages in many automobile compensation plans, see KEETON \& O'Connell, Basic Protection for the Traffic Victim: A Blueprint for Reforming AUTOMOBILE INSURANCE 358-62 (1965).

122 Cf. Blum \& Kalven, Public Law Perspectives on a Private law Problem: Auto Compensation Plans 34-36 (1965), suggesting that pain and suffering are real elements of personal injury and should not be easily dismissed. See also Starrs, $A$ Modest Proposal To Insure Justice for Victims of Crime, 50 MINN. L. REv. 285, 306-08 (1965).

123 See the suggestion that damages in a compensation plan might be paid according to the seriousness of the crime as well as the injury to the victim in Wolfgang, supra note 96, at 236-40. The British Working Party xejected the notion that compensation should be paid for the unpleasantness of the victim's expexience, CMND. 1406, at 15, and the plans have generally approached compensation as a contribution toward the consequences of injury, of which pain and suffering is one aspect.

124 Pain and suffering damages are limited under the New Zealand plan to N.Z. $£ 500$ (\$1,400). N.Z. Pub. Act 134, \& I9(3)(d).

125 Cameron, Compensation for Crimes of Violence: The New Zealand Experiment, 12 J. PuB. L. 367, 373 (1963).

126 The federal proposals define "personal injury" to include "mental or nervous shock." S. $2155, \S 102(4) ;$ H.R. 11818, § 102(4). Allowance is thus made for psychic damage as a medical problem, permitting payment of compensation for psychiatric treatment.

127 Rather than eliminate pain and suffering damages altogether as the Green bill does, or include them on the same basis as pecuniary loss as does the Yarborough bill, a 
Compensation comparable in scale to other social welfare programs and without pain and suffering damages would seriously delimit the common law principle that damages should be fully compensatory and tailored to the particular case. ${ }^{128}$ Hence treatment of compensation as an adjunct of workmen's compensation, as a proposal introduced in Maryland suggests, ${ }^{129}$ may be sensible. Injured victims and the dependents of victims killed would be reimbursed for their out of pocket expenses, while payments for loss of earnings and pecuniary loss to dependents would be measured as a percentage of actual earnings lost added to a fixed or base sum for disability. ${ }^{130}$ Such scheduled damages do not appear incompatible with the adjustment of awards in accordance with degrees of fault on the part of the victim, as the British feared; ${ }^{131}$ moreover, the system may have administrative advantages, tending to reduce delay and promote uniformity in the making of awards, which would be significant in a national plan or one operated by a large state where the volume of claims would be large. ${ }^{132}$

separate ceiling on pain and suffering damages might be imposed. Cf. N.Z. Pub. Act 134, $\S 19(3)(d)$. Such a compromise reduces the difficulty posed by large claims based primarily on nonpecuniary loss; under the Yarborough bill, victims with severe physical injuries for which damages approached the $\$ 25,000$ ceiling would be awarded little or no compensation for their pain, while victims with minor physical injuries could seek large pain and suffering awards. See Letter From Norval Morris, Professor of Law and Criminology of The University of Chicago Law School to Senator Ralph W. Yarborough, Aug. 21, 1965, copy on file at The University of Chicago Law Review office.

128 BLUM \& KaLVEN, op. cit. supra note 122, at 33.

129 Maryland S. Bill No. 151 (1966). The original Fry proposal envisaged a plan comparable to industrial accident benefits. Fry, Justice for Victims, The Observer (London), July 7, 1957, p. 8, col. 2, reprinted in Compensation for Victims of Criminal Violence: A Round Table, 8 J. PUB. L. 191, 192-93 (1959). The workmen's compensation analogy influenced the scale of awards in New Zealand. See note 114 supra and accompanying text.

130 Maryland S. Bill No. I5I, § I(4)(a)(3)(i) (1966). One difficulty of the workmen's compensation approach is that victims of crime, unlike injured workers, may be unemployed persons, housewives, children, and others whose disability does not affect earnings. See CMND. 1406, at 15. The Maryland bill answers this problem by allowing such victims to receive the base sum payments for total disability allowed under workmen's compensation apart from the further amount allowed for loss of earnings; the commission also has discretion to take the victim's earning power and other sources of income into account.

131 Cf. Maryland S. Bill No. 151, \&1(4)(a)(1) (1966), giving the commission discretion to diminish awards by reason of the victim's conduct. The British had thought that allowance for fault would be difficult to make with scheduled awards. JUSTIcE REPORT 12; CMND. 1406 , at 27. In practice, however, the British Board assesses the victim's fault as a percentage figure and reduces his award accordingly. See note 107 supra. This procedure could be applied to scheduled awards as well; workmen's compensation statutes in three states permit reduction of awards on a percentage basis for accidents caused by serious fault or intoxication of the employee. Colo. REv. Stat. ANN. § 81-13-4 (1963); UTAF Code ANN. \$ 35-1-14 (1953); WISc. STAT. ANN. \& 102.58 (1957). California permits a reduction for the employees "serious and wilful" negligence. CAL. LABOR CODE $\& 4551$ (50\% reduction except in certain enumerated instances).

132 The New Zealand Tribunal has decided only 26 cases in the first two and a half years of its existence. Report on the Operation of the Criminal Injuries Compensation Act 


\section{The Administration of Compensation}

The dimensions of the compensation plans do not require complex administrative machinery; either integration with an existing agency, the approach adopted in California, ${ }^{133}$ or creation of a small independent agency as under the British, New Zealand, and federal proposals ${ }^{134}$ seems a satisfactory solution. The small scale of the plans should not, however, obscure the importance of a systematic procedure for making awards. Compensation should be made with a minimum of delay and expense to victims, for not only would much of the benefit of awards for medical expenses and lost earnings be unrealized, particularly for uninsured victims, if awards were not paid quickly, but also those most in need are those least able to invest their resources in making a claim. ${ }^{135}$ If some compromise with the adversary process seems necessary to meet the needs of victims, ${ }^{138}$ however, the countervailing social interest in defeating invalid claims must also be recognized.

The federal proposals require that compensation claims be determined at an administrative hearing at which both victim and agency may be represented by counsel and may introduce evidence and crossexamine witnesses. ${ }^{137}$ The requirement that a hearing be held in every case imposes considerable burdens on claimants, particularly as most victims would need the assistance of counsel which would probably

of 1963. In 1965, the British Criminal Injuries Board received 2043 applications. Criminal Injuries Compensation Board, Report Dec. 31, 1965.

133 The California program is administered by the state Department of Social Welfare. See CAL. Welfare \& INst'Ns Code § 11211. The Maxyland plan would be carried out by the state Workmen's Compensation Commission. Maryland S. Bill No. 151 (1966). The California and New York Good Samaritan laws provide for an application to an existing public claims agency. See note 41 supra.

134 The British Board has five members. CMnd. 2323, at 4. The New Zealand Tribunal and the federal commissions proposed would have three. N.Z. Pub. Act 134, $\$ 4 ;$ S. 2155, § 201(a); H.R. 11818, § 201(a).

135 The JUSTICE REPORT urged that consideration be given to making compensation for immediate expenses available when needed. Justice REPORT 15-16. None of the plans, however, has made such provision.

136 The law has often required prospective plaintiffs to undergo delay and expense in bringing an action; as Blum and Kalven point out, "the deficiency of the common law as a first aid mechanism . . . is intrinsic to its liability for fault rationale." BLUM \&: KALVEN, op. cit. supra note 122, at 71. But where the issues to be determined bear not on personal liability but on eligibility for a government program, and where the benefits bear little relation to common law damages, it seems appropriate that a program meet emergency, needs and not deter claimants with the expense of making a claim, provided that the social interest in defeating unmerited claims can be satisfied.

137 S. 2155, § 205; H.R. 11818, § 205. Relevant evidence may be admitted regardless of its admissibility in a court of law. S. 2155, § 205(h); H.R. 11818, § 205(h). Proceedings are to be governed by the Administrative Procedure Act. S. 2155, $\S 20 \dot{5}^{(j)}$; H.R. 11818, $\S 205(\mathbf{j})$. 
become available ${ }^{138}$ only if claims were routinized as under workmen's compensation. ${ }^{139} \mathrm{~A}$ better procedure may be that adopted by the British and New Zealand plans, where the victim who submits an application receives an initial decision by one member of the agency after staff investigation of his claim; ${ }^{140}$ if unsatisfied, he may seek a hearing at which he is required to make his case. The hearing is apparently regarded as a form of appeal within the agency, most claims being decided on the basis of the initial staff investigation. ${ }^{141}$ The two-level procedure offers adequate safeguards to the agency as well as to the victim, ${ }^{142}$ and should also be less wasteful of time and money than requiring hearings in all cases. ${ }^{143}$

138 The federal proposals allow for the payment of legal fees out of but not in addition to awards made in an amount not exceeding $15 \%$ of awards over $\$ 1,000$. This provision, taken from the Federal Tort Claims Act, may be adequate when large awards are made, but Senator Yarborough concedes that victims seeking smaller sums may have difficulty in attracting legal assistance. Yarborough, supra note 94, at 260-61; see Attorneys Fees Before Government Bureaus, 25 ALA. LAw. 78 (1964).

139 In New York, the average attorney's fee in workmen compensation cases in one year was $2 \%$ of awards over $\$ 10,000$. Gelhorn \& Lauer, Administration of the New York Workmen's Compensation Law II, 37 N.Y.U.L. REv. 204, 220 (1962). The willingness of lawyers to appear in workmen's compensation cases despite limited fees is attributable partly to the existence of a highly specialized workmen's compensation bar, whose members handle large numbers of claims; lawyers have little to do in routine cases and their function is often purely formal. Id. at 217-22. Unless the volume of criminal compensation claims were sufficiently great to engender a specialized bar, and unless compensation proceedings were routinized to a comparable degree, it is doubtful that the needed legal assistance would be forthcoming.

140 CMnD. 2323, at 7. The language of the New Zealand law is identical with that of the federal proposals, but the Tribunal follows the British procedure of deciding claims on the basis of staff investigation. Report on the Operation of the Criminal Injuries Compensation Act of 1963.

141 An early report on the British scheme stressed the infrequency with which claimants request a hearing. CMND. 2782, at 5-6. Later figures show 802 awards made by a single member and 32 awards made after a hearing. Criminal Injuries Compensation Board, Report, Dec. 31, 1965.

142 The British Board would prefer, however, to have the power to request a hearing rather than leave the initiative wholly with the claimant. A single member when in doubt as to an award may sometimes deny the claim, and it has been suggested that the opinion of the full Board at a hearing might result in more decisions favorable to claimants. See CMnd. 2782, at 6-7.

143 The efficiency of settlement has been recognized under most workmen's compensation laws, which usually permit employee and insurer to settle uncontested claims without a hearing subject to commission approval. The vast bulk of claims are so settled. Dond, ADMINISTRATION OF WORKMEN's CoMpENSATTON 117-19 (1936). In New York a hearing is required; at one point the requirement was dropped, but it was reinstated when it appeared that employees were receiving fewer benefits than they were entitled to. At present, the automatic hearing is a formality at which claimants are not usually present; the examiner merely rubber-stamps staff approval of the settlement. Many feel that the hearing is no longer needed to protect the employee. Gelhorn \& Lauer, Administration 
Staff investigation would probably also be more efficient than a hearing procedure in gathering the information necessary to determine claims. Because police reports ${ }^{\mathbf{1 4 4}}$ and the conclusions of police officers will often be the most reliable information as to the circumstances of an incident, requesting submission of such reports to the agency ${ }^{145}$ seems more desirable than requiring the victim to produce such information. Similarly, provision for a medical examiner might relieve the victim of the expense of supplying medical testimony and also procure standardized and impartial evaluations for the agency. In routine cases, the information needed to make awards would be available to administrators from police and medical reports and the victim's account of the event; a hearing seems appropriate only when facts are disputed.

Although some commentators have feared that paying victims soon after their injuries are sustained would threaten the administration of criminal justice by weakening the victim's interest in cooperating in criminal prosecutions, ${ }^{146}$ a more likely danger is that the victim would have an overly strong interest in the conviction of the offender as a means of establishing his claim. The federal plans contribute somewhat to that incentive by providing that conviction of the offender will be conclusive evidence that a compensable crime has been committed; ${ }^{147}$

of the New York Workmen's Compensation Law (pts. I, 3), 37 N.Y.U.L. REv. 3, 25-28, 564, 607-15 (1962).

This experience suggests that the hearing may be needed to safeguard the claimant when private insurers or others have an adverse interest in opposing his claim, but might be unnecessary in a compensation plan administered by an agency which not only represents an adverse interest, but also serves as disinterested arbiter. A hearing which is a routine formality is not, in any case, a safeguard to either public or claimant.

144 The British plan requires that the victim have reported the crime to the police or that criminal proceedings have been initiated. CMND. 2323, at 5. The other plans do not contain such a requirement, which would seem desirable both to encourage citizen cooperation with the police and to discourage collusive claims. See JUSTICE REPORT 23-24.

145 It has been suggested that the task of investigating claims be delegated to police authorities who would certify to the agency their conclusions as to whether a crime had been committed. JUstrce REPORT 15-16; Childres, Compensation for Criminally Inflicted Personal Injury, 39 N.Y.U.L. REv. 444, 464-65 (1964). That procedure would impose new burdens on the police, however. Similarly, a further consideration militating against an automatic hearing requirement is that it would probably require police officers to spend much time testifying at hẹarings.

146 The only apparent rationale for this argument is that, once compensated, the victim would lose interest in criminal prosecution because he would be indifferent to whether or not the offender were convicted; his appetite for revenge would no longer demand gratification at the criminal trial. See, e.g., Inbau, Comment on the Proposal, Compensation for Victims of Criminal Violence: $A$ Round Table, 8 J. Pub. L. 201, 202-03 (1959); Mueller, Comment on the Proposal, Compensation for Victims of Criminal Violence: $A$ Round Table, 8 J. PuB. L. 218, 219-31 (1959).

147 S. 2155, § 205(i); H.R. 11818, § 205(i), following a comparable provision in the New Zealand law. The advantage to the claimant seems spurious, however, since the provision does not operate until conviction of the offender is final, generally many months in criminal proceedings. 
although it is unlikely that many victims would choose to postpone their claims until a conviction became final. More questionably, the federal plans provide for suspension of compensation proceedings at the request of the Attorney General when criminal prosecution is imminent; ${ }^{148}$ this provision does little to safeguard the interests of defendants, as an uncompensated victim is no less prejudiced than one who has already received an award and may indeed be more so if the offender's conviction will establish his eligibility for compensation. If frequently invoked, the suspension would cause considerable delay in the awarding of compensation and might tend to make compensation contingent on the outcome of criminal trials.

\section{CONCLUSION}

Analysis of recent compensation plans suggests that, once the decision to undertake such a program has been made, determination of its scope will be governed largely by considerations of economic and administrative feasibility. Uniformly contemplating modest benefits to a small class of persons, the plans are not ambitious in scale by comparison with other public programs and, with the possible exception of the undeserving victim, present no serious difficulties of execution. The significant question is thus the original one of whether such a program should be undertaken at all. Most people find the victim of crime an appealing object of concern, and because the plans are small in scale and do not, like medicare or other major reforms, threaten existing interests, they have evoked little opposition. The considerations against which the needs of victims of crime must be balanced have been largely obscured from view, and it might be contended that special legislation on behalf of the victim, while worthwhile, is of less pressing importance than other social problems which should be accorded priority. Such experience as exists today indicates, however, that legislators are disposed to decide the question of priorities in favor of the victim, and that their initial response will, when a plan has been in effect for even a short time, develop into the conviction that it would be unjust not to provide such assistance. ${ }^{149}$

148 S. 2155, § 301(f); H.R. 11818, \& 301(f).

149 "[M]any of the applications submitted relate to relatively minor injuries and the compensation paid is correspondingly small. But no one who is called to deal with those cases in which a blameless victim has been seriously disabled ... can fail to feel deeply what a worthwhile part is played in the full administration of justice by the power to award compensation." CMND. 2782, at 7. 